\title{
Effect of Recipes and Cultivars on Storage of Guava RTS
}

\author{
Ashwini K. Abhangrao ${ }^{1 *}$, A.K. Naidu ${ }^{2}$, S.S. Yadlod ${ }^{1}$ and Manisha Deshmukh ${ }^{3}$ \\ ${ }^{1}$ Vasantraonaikmarathwada Krishi Vidyapeeth Parbhani, India \\ ${ }^{2}$ Department of Horticulture Jabalpur (M.P), India \\ ${ }^{3}$ Punjab Rao Deshmukh Krishi Vidyapeeth, Akola, India \\ *Corresponding author
}

\begin{tabular}{|l|}
\hline Ke y w o r d s \\
Guava RTS, \\
Overall \\
acceptability, \\
Storage period, \\
Variety. \\
\hline Article Info \\
\hline $\begin{array}{l}\text { Accepted: } \\
\text { 12 March } 2017 \\
\text { Available Online: } \\
\text { 10 April } 2017\end{array}$ \\
\hline
\end{tabular}

\section{Keywords}

Guava RTS

Overall

acceptability

Storage period,

Variety.

Article Info

Accepted:

Available Online

10 April 2017

\section{A B S T R A C T}

The fruits of Lucknow - 49, Red fleshed variety and Apple guava were collected from the orchard of the College of Agriculture Jabalpur (M.P.).The fruits from the winter season crop(2007). Fully matured fruits were picked up and sorted, washed, cutting into pieces, mixing with water (1:1) then Passing through pulper to get guava pulp preparation after that guava pulp mixing with strained syrup solution (sugar+ water +acid heated to just to dissolve according to recipe), homogenization, cooling (at $40^{\circ} \mathrm{C}$ addition of sodium benzoate $750 \mathrm{ppm})$, filter, bottling, crown corking, pasteurization $\left(82^{\circ} \mathrm{C}\right.$ for $\left.15 \mathrm{~min}\right)$, cooling for RTS product. physical - chemical characters sensory quality characters(color, flavor, Taste, overall acceptability), Total Soluble solids, pH, Percent Acidity, Ascorbic acid content $(\mathrm{mg} / 100 \mathrm{mg})$ for $0^{\text {th }} 30^{\text {th }}, 60^{\text {th }}$ days observation were recorded. For acceptability of RTS Hedonic rating of colour was done by panel of 10 judges on 9 point hedonic scale. RTS was recorded. In experiment recipe 1 was $10 \%$ pulp, $11 \%$ T.S.S, $0.3 \%$ Acidity. Recipe 2 was $10 \%$ pulp, $11 \%$ T.S.S $0.4 \%$ Acidity. And recipe 3 was $10 \%$ pulp, $12 \%$ T.S.S, $0.3 \%$ Acidity., recipe 4 was $10 \%$ pulp, $12 \%$ T.S.S, $0.4 \%$ Acidity., recipe 5 was $10 \%$ pulp, $13 \%$ T.S.S $0.3 \%$ Acidity., recipe 6 was $10 \%$ pulp,13\%T.S.S, $0.4 \%$ Acidity was used. At shown that overall acceptability of RTS was highest in score(7.86) and recipe 1(10\% pulp, $11 \%$ T.S.S, $0.3 \%$ Acidity)followed by score(7.83 )and recipe $2(10 \%$ pulp,11\% T.S.S, $0.4 \%$ Acidity) Highest Ascorbic Acid content at recipe1 (10\% Pulp,11\% T.S.S, $0.3 \%$ Acidity).it was further observed At $0^{\text {th }}$ days for good for storage variety was Lucknow-49(8.10)followed by Apple guava(7.78) followed by(7.40). At $30^{\text {th }}$ days was also lucknow-49 (7.60)followed by apple guava(7.28)followed by red fleshed guava(7.10).at $60^{\text {th }}$ days was lucknow-49(7.28)followed by apple guava(7.15)followed by red fleshed guava(6.83).

\section{Introduction}

Guava (Psidium guajava L.) is one of the most nutritious fruit. It is richer source of vitamin" C" than Ber, Citrus, and Apple. Guava is grown commercially in North India because it's higher yielding capacity and good economic returns. In India Uttar Pradesh the largest grower produces best quality of Guava Bihar, Madhya Pradesh, Andhra Pradesh,
Tamilnadu, West Bengal, Punjab, Assam, Karnataka, Maharashtra are chief producers of quality guava.

India occupies nearly 150.9 lakh hectares of area with a production of 1710.6 million tonnes and with a productivity of 10.77 tonnes fruit per hectare per year (Yadav 
2002). However highest productivity recorded in M.P. 20.1 tones/ha.

Guava is an important fruit in international trade and domestic economy of several countries because of its easy cultivation under variable soils and climatic conditions (Menzel 1985). Fruits of guava are important ingredients in the human dietaries, due to their high nutritive value. Guava makes significant nutritional contribution to human being and cheaper source of the protective foods.

Guava has earned the popularity as "Poor man's apple" available in plenty to every person at a very low price during the season. It is no way to inferior to apple for its nutritional values. The fruit(berry) is an excellent source of vitamin ' $\mathrm{c}$ ' $(6300 \mathrm{mg} / 100 \mathrm{~g})$ and protein $1 \%$ content and has about dry matter (17\%) and moisture $(83 \%)$. The fruit is also rich in mineral like phosphorous $(23-37 \mathrm{mg} / 100 \mathrm{~g}$ ), calcium (14$30 \mathrm{mg} / 100 \mathrm{gm})$ and iron $(0.6-1.4 \mathrm{mg} / 100 \mathrm{~g})$ as well as vitamin like niacin, penthotenic acid, thiamine riboflavin and Vitamin" A" (Bose, 1999). Guava is normally consumed fresh as dessert fruit. It emit a sweet aroma which is pleasantly sweet and refreshing acidic in flavor. The whole fruit is edible along with skin. It is considered as one of the most delicious, luscious fruits, excellent salads, Pudding, jam, jelly, cheese, canned fruit, RTS, nectar, Squash and ice-creams and toffees can be made from guava fruit.

In central India especially in M.P guava grower generally takes Mrig bahar crops so seasonal glut occurs very often and sold at throw way prices. The storage of fruit is very difficult for longer period because of its perishable nature especially under tropical conditions. It is common experienced that 20 $25 \%$ of the fruit is completely damaged and spoiled before it reaches to the consumers
Yadav (1997). Therefore it is necessary to develop technology for better utilization of such a perishable fruit. In the state also it is grown on large scale and often it causes glut in the local market. The fruit grower does not have adequate facilities for extending shelf life of guava fruits hence most of the produce does not fetch good price. To overcome these problems there is need to find out suitable low cost processing techniques.

Therefore to utilize the produce at the time of glut and to save it from spoilage the development of low cost processing technology of guava fruit is a need of time. It will also generate enough opportunities of self - employment by starting small scale processing unit or cottage industry which will be remunerative to the growers. Thus the preparation of guava R.T.S beverage has a great scope.

\section{Materials and Methods}

The fruits of Lucknow-49, Red fleshed guava, Apple guava were collected from the orchard of the college of Agriculture J.N.K.V.V (M.P.). The fruits were collected from the winter season crop (2007) fully matured fruits were picked up and sorted out for the preparation of RTS. fruits were cut into small pieces, it can be sieved pulp, small pieces of guava mixing with water $1: 1$ and straining pulp, pulp was taken and dissolved with water after that TSS $\left(11,12\right.$ and $13^{\circ}$ brix) and acidity ( 0.3 and 0.4 percent) was maintained with help of sugar and citric acid as per recipe.

\section{Results and Discussion}

\section{Colour}

Data presented in table at 0th days was found in colour of RTS was maximum scored given in $R_{5}$ (8.13) followed by $R_{1}$ (8.10)and lowest score observed in $\mathrm{R}_{6}$ (7.83). With respect to 
varieties highest score was given by $\mathrm{V}_{1}$ Lucknow-49 (8.50) followed by $\mathrm{V}_{2}$ Apple guava (7.76) and Lowest recorded $V_{3}$ Red fleshed (7.71). As regards the combination maximum score recorded $\mathrm{R}_{1} \mathrm{~V}_{1}$ (8.84) followed by $\mathrm{R}_{2} \mathrm{~V}_{1}$ (8.80) and lowest score observed in $\mathrm{R}_{5} \mathrm{~V}_{3}$ (7.00) in RTS. The data presented in table at 30 day observation was in colour maximum score recorded in $\mathrm{R}_{5}$ (7.46) followed by $\mathrm{R}_{6}$ (7.26) lowest observed in $R_{3}$ (7.16). With respect to varieties maximum score recorded in $\mathrm{V}_{1}$ (7.53) followed by $\mathrm{V}_{2}$ (7.24) and lowest recorded in $\mathrm{V}_{3}(7.10)$ as per combination maximum score observed in $\mathrm{R}_{2} \mathrm{~V}_{1}, \mathrm{R}_{3} \mathrm{~V} 1, \mathrm{R}_{6} \mathrm{~V}_{1}$ (7.60) followed by $R_{5} V_{2}$ (7.50) lowest observed in $R_{3} V_{3}$ (7.00).

$0^{\text {th }}$ day that the colour rating of RTS decreased with increasing sugar content at after 30 days. At $0^{\text {th }}$ day observed that the RTS color rating was higher recipe $R_{5}$ at13 percent TSS which might be due to quite sugar and pulp ratio. At $30^{\text {th }}$ day observed colour rating was higher in recipe $R_{5}$ decreasing color rate. The RTS prepared from Lucknow-49 was rated best for colour at $0^{\text {th }}$ day and 30 day also second best apple guava lowest in Red fleshed guava (Harisimart and Dhawan, 1998).

\section{Flavor}

At $0^{\text {th }}$ day observation flavor was found in maximum scored in $R_{1}(8.00)$ followed by $R_{5}$ (7.86) and Lowest score observed in $R_{3}$ (7.70). With respect to varieties maximum score observed in $V_{1}$ (8.46) followed by $V_{2}$ (7.70) lowest score recorded in $V_{3}$ (7.28). As regards the combination for maximum score recorded in $R_{2} V_{1}$ (8.80) followed by $R_{5} V_{1}$ (8.70) and lowest recorded in $\mathrm{R}_{4} \mathrm{~V}_{3}$ (7.10) in RTS. At $30^{\text {th }}$ day observation was maximum flavor recorded in $R_{1}$ (7.56) followed by $R_{2}$ (7.53). Lowest recorded in $R_{5}$ and $R_{6}(7.30)$ with respect to varieties maximum score observed in $\mathrm{V}_{1}$ (7.61) followed by $\mathrm{V}_{2}$ (7.35) lowest recorded in $\mathrm{V}_{3}$ (7.23). As per combination the flavor of RTS maximum score $R_{3} V_{3}$ (7.90) followed by $R_{2} V_{1}$ (7.80) lowest recorded in $R_{2} V_{2}(7.10), R_{6} V_{3}$.

Flavor rating of RTS decreased with increasing of sugar content (TSS) at $0^{\text {th }}$ day followed by $30^{\text {th }}$ day and at $0^{\text {th }}$ day recipe $\mathrm{R}_{1}$ showed highest flavor followed by Recipe $R_{2}$ and lowest flavor in recipe $R_{3}$ this is due to higher pulp and sugar ratio with adequate acidity level. At $30^{\text {th }}$ day show recipe $\mathrm{R}_{1}$ show highest flavor followed by recipe $R_{2}$ this might due to inadequate sugar pulp and acidity ratio similar result was obtained Pandey and Singh (1999). Among the cultivars Lucknow-49 was rated best at $0^{\text {th }}$ day followed by 30 day for flavors over apple guava and red fleshed RTS due to their varietal character (Pandey et al., 1997).

\section{Taste}

At $0^{\text {th }}$ day observation flavor was found in maximum scored in $R_{1}$ (8.00) followed by $R_{5}$ (7.86) and Lowest score observed in $R_{3}$ (7.70). With respect to varieties maximum score observed in $V_{1}$ (8.46) followed by $V_{2}$ (7.70) lowest score recorded in $V_{3}$ (7.28). As regards the combination for maximum score recorded in $R_{2} V_{1}$ (8.80) followed by $R_{5} V_{1}$ (8.70) and lowest recorded in $\mathrm{R}_{4} \mathrm{~V}_{3}$ (7.10) in RTS. At $30^{\text {th }}$ day observation was maximum flavor recorded in $R_{1}$ (7.56) followed by $R_{2}$ (7.53) Lowest recorded in $R_{5}$ and $R_{6}$ (7.30) with respect to varieties maximum score observed in $V_{1}$ (7.61) followed by $V_{2}$ (7.35) lowest recorded in $\mathrm{V}_{3}$ (7.23). As per combination the flavor of RTS maximum score $R_{3} V_{3}$ (7.90) followed by $R_{2} V_{1}$ (7.80) lowest recorded in $R_{2} V_{2}$ (7.10) $R_{6} V_{3}(7.10)$.

Flavor rating of RTS decreased with increasing of sugar content (TSS) at $0^{\text {th }}$ day followed by $30^{\text {th }}$ day and at $0^{\text {th }}$ day recipe $R_{1}$ 
showed highest flavor followed by Recipe $\mathrm{R}_{2}$ and lowest flavor in recipe $R_{3}$ this is due to higher pulp and sugar ratio with adequate acidity level. At $30^{\text {th }}$ day show recipe $R_{1}$ show highest flavor followed by recipe $R_{2}$ this might due to inadequate sugar pulp and acidity ratio similar result was obtained Pandey and Singh (1999). Among the cultivars Lucknow-49 was rated best at $0^{\text {th }}$ day followed by 30 day for flavors over apple guava and red fleshed RTS due to their varietal character (Pandey et al., 1997).

At $0^{\text {th }}$ day observation taste was found in maximum scored in $R_{1}(7.86)$ followed by $R_{2}$ (7.83) and lowest score observed in $\mathrm{R}_{6}(7.60)$. With respect to varieties maximum score observed in $V_{1}(8.10)$ followed by $V_{2}$ (7.78) and lowest observed in $V_{3}$ (7.40). As regards the combination was highest score $R_{2} V_{1}$ (8.30) and followed by $R_{1} V_{1}$ (8.20) and lowest recorded as $\mathrm{R}_{5} \mathrm{~V}_{3}$ (7.20). At $30^{\text {th }}$ day observation was in Taste maximum recorded in $R_{2}$ (7.46) followed by $R_{1}$ (7.43) and lowest observed in $\mathrm{R}_{3}(7.20)$.

With respect to varieties maximum score recorded was in $V_{1}$ (7.60) followed by $V_{2}$ (7.40) and lowest in $V_{3}$ (7.15). With regards combination maximum score recorded in $R_{1} V_{1}$ (7.90) followed by $R_{2} V_{1}$ (7.80) Lowest score observed in $\mathrm{R}_{2} \mathrm{~V}_{3}(7.00), \mathrm{R}_{3} \mathrm{~V}_{3}(7.00) .0^{\text {th }}$ day observation obtained that recipe $R_{1}$ round to best rating. At $30^{\text {th }}$ day observation obtained that recipe $R_{2}$.

The highest test rating RTS due to addition or sugar in the pulp after $30^{\text {th }}$ day increase in quantity of sugar in RTS also reduce the taste rating. This is due to higher TSS value because of higher TSS reduced the colour and flavor of RTS ultimately reduce taste of RTS Jain et al., (1997). Among the cultivars it was found that RTS from Lucknow-49 was rated to best taste in $0^{\text {th }}, 30^{\text {th }}$ day. The next best apple guava show RTS taste rating in Red fleshed. These finding are in conformity with those at Harisimrat and Dhawan (1998).

\section{Overall acceptability}

At $0^{\text {th }}$ day overall acceptability observation maximum score was found in $R_{1}$ (7.86) followed by $\mathrm{R}_{2}$ (7.83) and lowest recorded in $\mathrm{R}_{6}$ (7.66). With respect to varieties $\mathrm{V}_{1}(8.10)$ given maximum score followed by $\mathrm{V}_{2}$ (7.78) and lowest score observed in $\mathrm{V}_{3}$ (7.40). As per combination $\mathrm{R}_{2} \mathrm{~V}_{1}$ (8.30) followed by $\mathrm{R}_{1} \mathrm{~V}_{1}$ (8.20) and lowest score recorded in $R_{4} V_{3}$ (7.20). At $30^{\text {th }}$ day observation was in overall acceptability maximum score was observed in $R_{1}$ (7.46) followed by $R_{2}$ (7.43). Lowest observed in $R_{3}$ (7.26). With respect to varieties maximum score observed $\mathrm{V}_{1}$ (7.60) followed by $V_{2}$ (7.28) Lowest observed in $V_{3}$ (7.10). With regards to combination maximum score followed by $\mathrm{R}_{1} \mathrm{~V}_{1}$ (7.90) followed by $R_{1} V_{2}$ (7.80) and lowest in $R_{3} V_{3}$ (7.00).

At $0^{\text {th }}$ day recipe $\mathrm{R}_{1}$ was on rating colour, flavor, taste followed by $30^{\text {th }}$ day reduced rating of overall acceptability at $0^{\text {th }}$ day was reported that by Pandey and singh (1999). This is due to better colour excellent flavor good taste and attractiveness. The higher score from overall acceptability of RTS was found in Lucknow-49 at 0thdays followed by $30^{\text {th }}$ day. Next best apple guava RTS showed high overall acceptability followed Red fleshed guava.

Among storage period $0^{\text {th }}, 30^{\text {th }}$ of RTS overall acceptability of RTS decreased slightly with increase in storage decreased slightly with increase in storage period. Recipe $\mathrm{R}_{1}$ show highest score for overall acceptability followed by recipe $R_{2}$ and $R_{3}$. This is due to loss of colour and flavor of RTS which are responsible to change in overall acceptability (Pandey and Singh, 1999). 


\begin{tabular}{|c|c|c|c|c|c|c|c|c|}
\hline \multicolumn{9}{|c|}{ Table.1 Effect of recipes, cultivars and their interaction on storage of Guava RTS at 30th day } \\
\hline & & & $\begin{array}{l}\text { Oth } \\
\text { days }\end{array}$ & & & & 0th Days & \\
\hline & Colour & Flavour & Taste & Overall & TSS & $\%$ Acidity & $\mathrm{pH}$ & Ascorbic \\
\hline $\begin{array}{c}\text { FACTOR } \\
\text { A }\end{array}$ & & & & ACCEPTABILITY & & & & ACID \\
\hline $\mathrm{R}_{1}$ & 8.10 & 8.00 & 7.86 & 7.86 & 12.31 & 2.00 & 3.50 & 19.86 \\
\hline $\mathrm{R}_{2}$ & 8.06 & 7.83 & 7.83 & 7.83 & 13.36 & 2.10 & 3.58 & 18.01 \\
\hline $\mathrm{R}_{3}$ & 7.83 & 7.70 & 7.80 & 7.80 & 13.43 & 2.20 & 3.65 & 20.03 \\
\hline $\mathrm{R}_{4}$ & 8.03 & 7.76 & 7.70 & 7.70 & 11.14 & 2.40 & 3.55 & 15.29 \\
\hline $\mathrm{R}_{5}$ & 8.13 & 7.86 & 7.73 & 7.73 & 12.31 & 2.50 & 3.57 & 17.25 \\
\hline $\mathrm{R}_{6}$ & 7.90 & 7.73 & 7.60 & 7.66 & 12.30 & 2.30 & 3.61 & 15.26 \\
\hline MEAN & 8.00 & 7.81 & 7.76 & 7.76 & 12.46 & 2.20 & 3.56 & 17.60 \\
\hline SEM \pm & 0.001 & 0.003 & 0.004 & 0.100 & 0.001 & 0.005 & 0.004 & 0.100 \\
\hline $\begin{array}{c}\text { CD AT } \\
5 \%\end{array}$ & 0.003 & 0.010 & 0.001 & 0.003 & 0.004 & 0.009 & 0.001 & 0.288 \\
\hline \multicolumn{9}{|l|}{$\begin{array}{c}\text { FACTOR } \\
\text { B } \\
\end{array}$} \\
\hline $\mathrm{V}_{1}$ & 8.50 & 8.46 & 8.10 & 8.10 & 12.68 & 2.41 & 3.70 & 17.76 \\
\hline $\mathrm{V}_{2}$ & 7.76 & 7.70 & 7.78 & 7.78 & 12.50 & 2.21 & 3.59 & 16.25 \\
\hline $\mathrm{V}_{3}$ & 7.71 & 7.28 & 7.40 & 7.40 & 12.22 & 2.20 & 3.40 & 17.76 \\
\hline MEAN & 18.83 & 23.44 & 18.35 & 18.35 & 29.25 & 5.35 & 8.42 & 39.93 \\
\hline SEM \pm & 0.0017 & 0.0047 & 0.0054 & 0.1419 & 0.0020 & 0.0064 & 0.0089 & 0.1419 \\
\hline $\begin{array}{c}\text { CD AT } \\
5 \%\end{array}$ & 0.0049 & 0.0014 & 0.0016 & 0.1419 & 0.0559 & 0.0130 & 0.0018 & 0.407 .19 \\
\hline \multicolumn{9}{|l|}{$\mathrm{AXB}$} \\
\hline $\mathrm{R}_{1} \mathrm{~V}_{1}$ & 8.84 & 8.60 & 8.20 & 8.20 & 12.54 & 2.30 & 3.68 & 21.30 \\
\hline $\mathrm{R}_{2} \mathrm{~V}_{1}$ & 8.80 & 8.80 & 8.30 & 8.30 & 13.62 & 2.30 & 3.70 & 19.05 \\
\hline $\mathrm{R}_{3} \mathrm{~V}_{1}$ & 8.00 & 8.20 & 8.00 & 8.00 & 13.70 & 2.50 & 3.72 & 21.30 \\
\hline $\mathrm{R}_{4} \mathrm{~V}_{1}$ & 8.70 & 8.30 & 8.00 & 8.00 & 11.30 & 2.50 & 3.71 & 16.89 \\
\hline $\mathrm{R}_{5} \mathrm{~V}_{1}$ & 8.50 & 8.70 & 8.10 & 8.10 & 12.54 & 2.50 & 3.70 & 19.25 \\
\hline $\mathrm{R}_{6} \mathrm{~V}_{1}$ & 8.60 & 8.20 & 8.10 & 8.10 & 12.54 & 2.40 & 3.71 & 16.80 \\
\hline $\mathrm{R}_{1} \mathrm{~V}_{2}$ & 7.90 & 7.80 & 7.90 & 7.90 & 12.40 & 2.20 & 3.64 & 19.09 \\
\hline $\mathrm{R}_{2} \mathrm{~V}_{2}$ & 7.80 & 7.50 & 7.80 & 7.80 & 13.48 & 2.00 & 3.64 & 20.30 \\
\hline $\mathrm{R}_{3} \mathrm{~V}_{2}$ & 7.50 & 7.60 & 7.80 & 7.80 & 13.40 & 2.00 & 3.65 & 18.00 \\
\hline $\mathrm{R}_{4} \mathrm{~V}_{2}$ & 7.70 & 7.90 & 7.70 & 7.70 & 11.12 & 2.40 & 3.65 & 20.30 \\
\hline $\mathrm{R}_{5} \mathrm{~V}_{2}$ & 8.10 & 7.40 & 7.90 & 7.90 & 12.40 & 2.40 & 3.36 & 15.00 \\
\hline $\mathrm{R}_{6} \mathrm{~V}_{2}$ & 7.60 & 8.00 & 7.60 & 7.60 & 12.25 & 2.00 & 3.63 & 17.76 \\
\hline $\mathrm{R}_{1} \mathrm{~V}_{3}$ & 7.70 & 7.60 & 7.50 & 7.50 & 12.00 & 2.10 & 3.20 & 18.00 \\
\hline
\end{tabular}




\begin{tabular}{|c|c|c|c|c|c|c|c|c|}
$\mathrm{R}_{2} \mathrm{~V}_{3}$ & 7.60 & 7.20 & 7.40 & 7.40 & 13.00 & 2.20 & 3.40 & 17.00 \\
\hline $\mathrm{R}_{3} \mathrm{~V}_{3}$ & 8.00 & 7.30 & 7.60 & 7.40 & 13.20 & 2.40 & 3.60 & 18.00 \\
\hline $\mathrm{R}_{4} \mathrm{~V}_{3}$ & 7.70 & 7.10 & 7.40 & 7.20 & 11.00 & 2.10 & 3.30 & 14.00 \\
\hline $\mathrm{R}_{5} \mathrm{~V}_{3}$ & 7.00 & 7.50 & 7.20 & 7.30 & 12.00 & 2.20 & 3.40 & 16.00 \\
\hline $\mathrm{R}_{6} \mathrm{~V}_{3}$ & 7.80 & 7.00 & 7.30 & 7.40 & 12.00 & 2.20 & 3.50 & 14.00 \\
\hline $\mathrm{SEM} \pm$ & 0.00297 & 0.00158 & 0.00543 & 0.245831 & 0.00354 & 0.011066 & 0.0089 & 0.245831 \\
\hline $\mathrm{CD}$ & & & & & & & & \\
$\mathrm{AT} 5 \%$ & 0.0085 & 234 & 0.0027 & 0.008133 & 0.01016 & 0.02244 & 0.003128 & 0.705081 \\
\hline
\end{tabular}

Table.2 Effect of recipes, cultivars and their interaction on storage of Guava RTS at 30th day

\begin{tabular}{|c|c|c|c|c|c|c|c|c|}
\hline & & & 30 Days & & & & & \multirow{3}{*}{$\begin{array}{c}\text { Ascorbi } \\
\text { Acid }\end{array}$} \\
\hline & Colour & Flavour & Taste & \multirow{2}{*}{$\begin{array}{c}\text { Overall } \\
\text { Acceptability }\end{array}$} & TSS & $\mathrm{pH}$ & $\%$ Acidity & \\
\hline Factor A & & & & & & & & \\
\hline $\mathrm{R} 1$ & 7.20 & 7.56 & 7.43 & 7.46 & 14.25 & 2.53 & 1.73 & 13.43 \\
\hline $\mathrm{R} 2$ & 7.23 & 7.53 & 7.46 & 7.43 & 14.94 & 2.70 & 1.80 & 11.58 \\
\hline $\mathrm{R} 3$ & 7.16 & 7.26 & 7.20 & 7.26 & 15.34 & 2.90 & 2.00 & 9.76 \\
\hline $\mathrm{R} 4$ & 7.20 & 7.43 & 7.30 & 7.30 & 13.08 & 2.56 & 2.23 & 13.15 \\
\hline $\mathrm{R} 5$ & 7.46 & 7.30 & 7.40 & 7.20 & 13.17 & 2.66 & 2.20 & 12.47 \\
\hline R6 & 7.26 & 7.30 & 7.30 & 7.36 & 14.90 & 2.80 & 2.00 & 10.03 \\
\hline MEAN & 7.24 & 7.39 & 7.34 & 7.32 & 14.27 & 2.69 & 1.99 & 11.70 \\
\hline SEM \pm & 0.006 & 0.001 & 0.007 & 0.004 & 0.002 & 0.004 & 0.003 & 0.096 \\
\hline CD AT $5 \%$ & 0.002 & 0.003 & 0.002 & 0.001 & 0.005 & 0.001 & 0.007 & 0.028 \\
\hline \multicolumn{9}{|l|}{ FACTORB } \\
\hline v1 & 7.53 & 7.61 & 7.60 & 7.60 & 14.63 & 3.21 & 2.08 & 14.62 \\
\hline $\mathrm{v} 2$ & 7.24 & 7.35 & 7.40 & 7.28 & 14.27 & 2.63 & 1.88 & 12.98 \\
\hline v3 & 7.10 & 7.23 & 7.15 & 7.10 & 13.90 & 2.23 & 2.03 & 10.98 \\
\hline MEAN & 17.14 & 17.37 & 17.38 & 17.25 & 33.53 & 6.58 & 4.64 & 31.26 \\
\hline SEM \pm & 0.0084 & 0.0014 & 0.0064 & 0.0060 & 0.0042 & 0.0011 & 0.0036 & 0.1397 \\
\hline CD AT $5 \%$ & 0.0024 & 0.0041 & 0.1837 & 0.0017 & 0.0070 & 0.0011 & 0.0010 & 0.4007 \\
\hline \multicolumn{9}{|l|}{ AXB } \\
\hline R1V1 & 7.50 & 7.80 & 7.90 & 7.90 & 14.40 & 3.30 & 1.90 & 17.30 \\
\hline $\mathrm{R} 2 \mathrm{~V} 1$ & 7.60 & 7.60 & 7.80 & 7.80 & 15.54 & 3.20 & 1.90 & 16.00 \\
\hline R3V1 & 7.60 & 7.70 & 7.63 & 7.60 & 15.62 & 3.20 & 2.00 & 15.05 \\
\hline R4V1 & 7.40 & 7.40 & 7.50 & 7.50 & 13.26 & 3.10 & 2.40 & 14.20 \\
\hline R5V1 & 7.50 & 7.60 & 7.20 & 7.20 & 13.30 & 3.20 & 2.30 & 12.80 \\
\hline R6V1 & 7.60 & 7.60 & 7.60 & 7.60 & 15.70 & 3.30 & 2.00 & 12.39 \\
\hline
\end{tabular}




\begin{tabular}{|c|c|c|c|c|c|c|c|c|}
\hline R1V2 & 7.20 & 7.60 & 7.40 & 7.40 & 14.25 & 1.90 & 1.70 & 15.30 \\
\hline R2V2 & 7.23 & 7.10 & 7.50 & 7.50 & 14.40 & 2.80 & 1.80 & 14.00 \\
\hline R3V2 & 7.16 & 7.30 & 7.30 & 7.20 & 15.40 & 3.00 & 2.10 & 13.00 \\
\hline R4V2 & 7.20 & 7.70 & 7.60 & 7.10 & 13.08 & 2.60 & 2.20 & 13.00 \\
\hline R5V2 & 7.46 & 7.40 & 7.40 & 7.30 & 13.17 & 2.70 & 2.30 & 11.00 \\
\hline R6V2 & 7.26 & 7.60 & 7.50 & 7.20 & 14.90 & 2.80 & 2.10 & 11.39 \\
\hline R1V3 & 7.20 & 7.60 & 7.10 & 7.10 & 14.27 & 2.40 & 1.60 & 14.00 \\
\hline R2V3 & 7.10 & 7.30 & 7.00 & 7.00 & 14.12 & 2.10 & 1.80 & 13.00 \\
\hline R3V3 & 7.00 & 7.90 & 7.00 & 7.00 & 14.90 & 2.50 & 1.90 & 12.00 \\
\hline R4V3 & 7.10 & 6.80 & 7.00 & 7.30 & 15.00 & 2.00 & 2.10 & 12.00 \\
\hline R5V3 & 7.10 & 7.20 & 7.30 & 7.20 & 13.00 & 2.10 & 2.00 & 10.30 \\
\hline R6V3 & 7.20 & 7.10 & 7.30 & 7.30 & 14.90 & 2.30 & 1.90 & 10.30 \\
\hline SEM 1 & 0.001462 & 0.002487 & 0.011091 & 0.001041 & 0.00421 & 0.001143 & 0.00624 & 0.023628 \\
\hline CD AT5\% & 0.004194 & 0.007133 & 0.31812 & 0.002987 & 0.00121 & 0.00328 & 0.001789 & 0.06776 \\
\hline
\end{tabular}

\section{TSS}

At $0^{\text {th }}$ day observation was found in TSS maximum scored in $R_{3}$ (13.43) followed by $R_{2}$ (13.36) lowest observed in $\mathrm{R}_{4}$ (11.14). With respect to varieties $V_{1}$ (12.68) recorded found that maximum score observed in $\mathrm{R}_{2} \mathrm{~V}_{1}$ (13.62) followed by $R_{2} V_{2}$ (13.48) lowest recorded in $\mathrm{R}_{4} \mathrm{~V}_{3}$ (11.00). At 30 days observation was TSS maximum score in $R_{3}$ (15.34) followed by $R_{6}$ (14.90) lowest observed in $R_{4}$ (13.08) with respect to varieties maximum scored observed in $\mathrm{V}_{1}$ (14.63) followed by $\mathrm{V}_{2}$ (14.27) lowest score observed in $\mathrm{V}_{3}$ (13.90). As per combination maximum score observed in $\mathrm{R}_{6} \mathrm{~V}_{1}$ (15.70) followed by $R_{3} V_{1}$ (15.62) and lowest observed in $R_{5} V_{3}(13.00)$. At $0^{\text {th }}$ days recipe $R_{3}$ show higher TSS content (13.43) which have lower pulps: sugar ratio and acidity followed by $30^{\text {th }}$ day observation recipe $R_{3}$.

At $0^{\text {th }}$ days recipe $\mathrm{R}_{3}$ show higher TSS content (13.43) which have lower pulps: sugar ratio and acidity followed by $30^{\text {th }}$ day observation recipe $\mathrm{R}_{3}$ higher TSS content, recipe $\mathrm{R}_{1}$ show higher TSS content in RTS as increase in TSS of the RTS beverage may possibly be due to conversion of polysaccharides into sugar (Ashrat 1987 and Rabbani,1992).
It was further observed that the TSS value of different cultivars also affected the TSS content of the recipes significantly. The highest TSS observed in $0^{\text {th }}, 30^{\text {th }}$ day in RTS prepared with Lucknow-49 followed by apple guava and lowest in Red fleshed guava this was also due to varietal characters.

\section{Acidity}

At $0^{\text {th }}$ day observation was found Acidity maximum recorded in $R_{5}(2.50)$ followed by $R_{4}$ (2.40) and lowest observed in $\mathrm{R}_{1}$ (2.00). With respect to varieties maximum scored in $\mathrm{V}_{1}$ (2.41) followed by $\mathrm{V}_{2}$ (2.21) lowest in $\mathrm{V}_{3}$ (2.20). As per combination maximum scored observed $\mathrm{R}_{3} \mathrm{~V} 1$ (2.50), $\mathrm{R}_{4} \mathrm{~V}_{1}$ (2.50), $\mathrm{R}_{5} \mathrm{~V}_{1}$ (2.50) followed by $\mathrm{R}_{6} \mathrm{~V}_{1}$ (2.40). Lowest recorded in $\mathrm{R}_{2} \mathrm{~V}_{2}$ (2.00), $\mathrm{R}_{3} \mathrm{~V}_{2}$ (2.00). At 30 day observation in percent acidity maximum score observed in $\mathrm{R}_{4}$ (2.23) followed by $\mathrm{R}_{5}$ (2.20) lowest score observed in $R_{1}$ (1.73). With respect to varieties maximum scored observed in $\mathrm{V}_{1}$ (2.08) and followed by $\mathrm{V}_{3}$ (2.03) lowest observed in $\mathrm{V}_{2}$ (1.88). As per combination maximum score $\mathrm{R}_{4} \mathrm{~V}_{1}$ (2.40) followed by $\mathrm{R}_{5} \mathrm{~V}_{1}$ (2.30) and Lowest observed in $\mathrm{R}_{6} \mathrm{~V}_{3}(1.90)$ in RTS. 
At $0^{\text {th }}$ day observation maximum acidity showed at recipe $\mathrm{R}_{5}$ and minimum acidity showed at recipe $\mathrm{R}_{1} 30^{\text {th }}$ day observation maximum acidity shows at recipe $R_{3}$, recipe $R_{6}$, followed by recipe $R_{2}$. It clearly indicates that increase in TSS of RTS reduced the acidity of RTS (Baramanray, 1996).

\section{References}

A.O.A.C.(1980). Method of Analysis of the Association of Official Agricultural Chemists, Washington, D.C., USA.

Amerine, M.A, Pangborn, R.M. and Rossler, E.B. (1965). Principles of sensory evaluation of food academic Press, New York.

Baramanray, A, Gupta O.P. and Dhawan, S.S (1995). Evaluation of Guava (Psidium guajava L.) hybrids for making nectar. Haryana J.Hort. Sci., 24(4):196-204

Bose T.K, Mitra, S.K; farooqui, A.A. and sandhu, M.K. (1999). Tropical Horticulture, 1: 297.

Chatterjee, D, Singh, U.P, Thakur, S. and Kumar, R. (1992). A note on the bearing habit of guava (Psidium guajava L.). Haryana. J. Hort.sci., 21(1 and 2): 69-71

Deka B.C, Vijay sethi; Poonam, Suneja; Shrivastava, V.K. (2004). Physicochemical changes of lime- aonla Spiced beverage during storage. J. of Food science and Technology, Mysore., 41(3): 329-332.

Deka, B.C, Vijaysethi; Anantasaikia (2005). Changes in quality of mango-pineapple spiced beverage during storage. Indian $J$. Hort., 62(1): 71-75.

Garg, N, Kalra, S.K. and Tondon, D.K. (1993). Quality evaluation of market raw mango powder and mango leather. Beverage and Food World, 20(2):13-14, 18.

Harisimrat, K. Bons and S.S. Dhawan (2003). Effect of preserved guava pulp on the quality of ready to serve beverage. Centre of food Science and technology CCS Haryana Agriculture University, Hisar Crop Res., 25(2): 360-363.

Harnanan, S.W, Bains,G.S. and Singh K.K.
(1980). Studies on processing of pink and white fleshed guava varieties of pulp.

Harisimrat, K. and Dhawan, S.S (1998). Preparation of guava fruit bar poster abstract. IFCON, 0-40:533.

Imran Ahmad; Rafinullah Khan; Muhammad Ayub (2000). Effect of added sugar at various concentrations on the storage stability of guava pulp. Sarhad $J$. Agricult., 16(1): 89-93.

Iqbal, S, Yasmin, A; Wadud, S, Shah, W.H. (2001). Production, storage, packing and quality evaluation of guava nectar. Pak. $J$. Food Sci., V.II (1-4): 33-36.

Jain P.K. and Asati, V.K. (2004). Evaluation of Guava cultivars for pulp preparation. $J$. Food Sci. Technol, Mysore, 41(6): 684686

Jain, S.K, Khuradiya, D.S. (2004). Vitamin 'C' enrichment of fruit juice base blending of Indian gooseberry (Emblica officnalis Gaertn) juice. Plants Foods For Human Nutrition, 59(2):63-66.

Jain, V; Tiwari. B.L. and Sharma, H.G. (1997). Evauation of early mango varieties for preparation of beverage as nectar and RTS. Orissa J. Hort., 25 (1): 40-45:8.

Kalra, S.K. and Revanthi, G. (1983). Chemical and microbial evaluation stored guava pulp in P.V.C container. J.Fd. Sci. Technology., 20(3): 118-120.

Khburdiya, D.S. and Sagar, V.R. (1991). Note on processing and storage of guava nectar. Indian J. Hort., 48(1): 19-21.

Kumar, R.S, Manimegalai, G. (2005). Studies on storage stability of whey based papaya juice blended R.T.S beverage. J. Food Sci. Technol., Mysore, 42(2):185-188.

Pagano Garcia, F, Medina Bracamonte M.L, Araujo, F. (2002). Evaluation of Free amino acids in guava (Psidium guajava L.) pulp destined for nectar preparation.

Palaniswamy, K.P, Mathurkrishnan, C.R. Shanmugvelu, K.G. (1974) studied on evaluation of certain mango varieties of Tamil Nadu for pulp destined for nectar production.

Pandey A.K. (2004). Study about the storage storability of Guava Beverage. Prog. 
Hort., 36(1): 142-145.

Pandey A.K. and Singh I.S. (1999). Studies on preparation of guava ready to serve beverage. Indian. J. Hort.., 56(2): 130132.

Pandey, K.K, Sharma A.B. and Patel M.P. (1997). The varietals evaluation of Guava (Psidium guajava L.). Ad. Plant Sci., 10(1): 157-163.

Pandey, A.K, and singh I.S. (1998). Physicochemical studies on utilization of guava cultivars. Prog. Hort., 30(1/2): 73-75.

Proceedings of the inter American Society for Tropical Horticulture, 2000. 42: 292-296.

Panse PV, Sukhatme VG (1967) Statistical method of agricultural worker. ICAR publication, New Delhi.

Rabbani, A. (1992). Studies on post -harvest technology of sucking Mangoes. Ph.D Thesis N.D. Univ. Agric. Technol., Faizabad.

Ramajayam, D, Jagannath, S., Syamsundar, Joshi, Sivakumar, K.C. (2002). Preparation of ready to serve (RTs) and squashes from simarouba fruits. Current Research University of Agricultural Sciences, Banglore, 31(7/8): 111-113.

Roy, K.S. And Singh, R.N. (1979). Studies on utilization on bael fruit for processing. Indian Fd. Packer, 46(6): 19-22.

Sagar, V.R. and Maini, S.B. (1993). Economic Utilization of rainy season guava drying aspects. Indian Fd. Packer, 46(6): 19-22.

Sahni, C.K., Khurdiya, D.S. and Dalal, M.A. (1994). Studies on quality and carotene profile of mango pulp as influenced by temperature and aditives. Indian J. Hort., 51(3): 229-233.

Sarvanan, K., Godara, R.K., Goyal, R.K., Sharma, R.K. (2004). Processing of papaya fruit for the preparation of ready to serve beverage and its quality. Indian J. Hill Farm., 14(1/2): 49-55.

Sethi V. and Jindal, P.C. (1997). Evaluation of new grape hybrid juice for processing. Haryana J. Hort. Sci., 26(3-4): 208

Sethi, V. and Maini, S.B. (1991). Studies on storage of Mango pulp. Indian J. Hort., 48(8): 228-231.

Shrivastava, R.P. and Kumar, S. (1992).Fruit and vegetable preservation principles and practices, pp. 81-83.

Singh B.P., Kalra, S.K., Tondon D.K.(1990). Behaviour of Guava cultivars during ripening and Storage. Haryana J. Hort. Sci., 19: 1-2 1-6.

Snecdor, G.M. and Cochron, W.C. (1967). Statistical methods. Oxford and IBH Publishing Co. Calcutta.

Tondon, D.K., Kalra, S.K., Singh, H., Chadha, K.I. (1983). Physico-chemical characterstics or same guava Varieties. Prog. Horticult., 15: 1/2, $42-44$.

Tripathi, S.N., Lyre, B.C., Shrivastava, R.C. and Pathak, A.C. (1971). Studies on qualitative characteristics of some guava varieties (Psidium guajava L.). J.N.K.V.V Res. J., 5(1): 32-34.

Yadav, I.S. (1994). Search for quality cultivars. The hindu Survey of Indian Agriculture, pp.132.

\section{How to cite this article:}

Ashwini K. Abhangrao, A.K. Naidu, S.S. Yadlod and Manisha Deshmukh. 2017. Effect of Recipes and Cultivars on Storage of Guava RTS. Int.J.Curr.Microbiol.App.Sci. 6(4): 1301-1309.

doi: https://doi.org/10.20546/ijcmas.2017.604.159 